\title{
PROTEST ON THE ROAD TO FREEDOM: THE WOMEN OF MADAGASCAR
}

\author{
Cynthia Holder Rich \\ School of Theology \\ University of KwaZulu-Natal ${ }^{1}$
}

\section{Women's Revolt, Story and Analysis}

On April 3, 1822, King Radama, monarch of the Merina kingdom of Madagascar, cut his hair. Before he cut them, Radama had long, intricately woven braids, and his hair had never been cut. The braids of the monarch, and the way in which they were arranged on his head, held political meaning for the Merina people. Madagascar historian Pier Martin Larson notes that the braids on Radama's head were "divided and organized (into their) proper social and political order", signifying the division and organization of the various status groups of the kingdom. ${ }^{2}$ Order in the king's hair was thought to signify order in the kingdom, which would bring fertility. Cutting one's hair was a sign of subordination. When a king died, the subjects were required to cut their hair to signify that they accepted subordination to the new king. It was "an overt sign of obedience, an enactment of the end of an old order and the beginning of a new one."3 The only people in the kingdom who commonly would be seen with short hair were slaves and condemned criminals. ${ }^{4}$

There was more, however, than disorder, infertility and subordination in the cutting of the king's braids. Radama had decided to form a standing army, a new form of service that was required of the men of the kingdom. Before 1822, Merina men were called to defend the kingdom when need arose; now, they would be required to serve long periods of time, and were to be based in the capital, far from their homes and personal responsibilities. A part, then, of the meaning of the new hairstyle was a new world order - and in the new world order displayed in his now-chaotic, disordered hairstyle, Radama was fostering allegiance to a European model in both hair and governance - rather than that of former Malagasy leaders. Radama's haircut occurred four years after the first Protestant missionaries arrived on the island, at Radama's invitation. These "technicians", as the King understood them, had been invited to the island to help educate the people in the ways of the world outside Madagascar, and to codify the language in Roman script so that the Malagasy could become literate and the kingdom could more easily transact business with societies which understood literacy as part of civilized life. Larson notes that "Radama demonstrated that the new cultural and religious ideas being formulated by British missionaries ... would remain as permanent features of royal politics." By 1822, it had become clear to many aristocratic Merina that these new religious ideas were opposed to traditional understanding. The Christian God, in the ways this God and His worship were interpreted by the missionaries, was different from traditional understandings of Deity,

1. Cynthia Holder Rich has taught for six years at the Lutheran Graduate Seminary of the Malagasy Lutheran Church and Amboniavaratra Theological College of the Church of Jesus Christ in Madagascar. She is a PhD candidate in Theology and Development in the School of Theology, University of Natal.

2. Pier Martin Larson, Making Ethnic Tradition in a Pre-Colonial Society: Culture, Gender and Protests in the Early Merina Kingdom, 1750-1822. Doctoral Dissertation, University of Wisconsin-Madison, USA, 1992; 474.

3. Ibid., 471

4. Ibid.

5. Ibid. 
particularly in the ways in which highlands Malagasy women were given leadership opportunities in traditional ritual. ${ }^{6}$ In contrast, “...the new religious protégés of the king were fashioning a new theology with an exclusively masculine God", who would be served primarily by male leadership. ${ }^{7}$ Further, Larson reports that noble children were required by Radama to go to the mission school set up at the palace by the missionaries. This requirement was understood as fanompoana, required service, and was the first time such service had been required of children. This fanompoana "removed children from the household economy and socialized them in a setting far from parental control." It becomes clear that Radama did not cut his hair on a whim, and that his singular act was correctly interpreted by the aristocratic community of the kingdom as part and parcel of a whole system of new forms of oppression and unfreedom that were being visited on the Malagasy people throughout the kingdom as a result of the king's encounter and relationship with Europeans.

Differing accounts of what happened next exist, and all those available to us were written by men - either aristocratic Malagasy scribes, or British missionaries, all of whom had underlying agendas and purposes for their writing which impacted the tone of their reports. ${ }^{9}$ While the male accounts differ in many respects, it is clear that when the king cut his hair, it was the aristocratic women of the kingdom who rose to protest. Five thousand women gathered on the outskirts of the capital city to protest the king's new hairstyle and all its portents.

Radama responded by calling together his new army and exacting a vow of loyalty from his troops, knowing that as the army was made up of aristocratic men and the protestors were aristocratic women, the probability existed that he would be ordering the army to attack their mothers, wives, sisters and daughters. Then he sent a message to the women, asking who had sent them. They responded that they had come of their own accord. He sent another message, urging them to go home; they responded that they were concerned for the future of the kingdom and for the king himself, and intimated that he was getting bad advice from the Europeans. Poignantly, the women reminded Radama that they, the aristocratic women of the kingdom, had been his nursemaids and caregivers, which meant that they expected - and deserved - his respect.

Radama responded by sending armed troops to the protest site, with the message that as they were so upset by his haircut, he would arrange that their hair would never grow again; on Radama's order the five identified leaders of the protest were executed, and the rest were corralled and kept for three days with no food, water or shelter. The protestors were then sent home, encouraged to "attend to their domestic duties" with the warning that they must "leave the business of government to (the king) and not interfere again in the affairs of the

6. Cf. Celine Ratovoson, "La Femme Malgache Responsable de son Environnement Physique et Systemes Religieux", in CIDST, La Femme Malgache Responsable de son Environnement. Antananarivo: L'Académie Malgache, 1989; 128. Ratovoson refers to women as "les médiateurs privilégiés entre les ancêtres et celui des vivants"(the privileged mediators (mediators of choice) between the ancestors and the living). See also Lesley A. Sharp, The Possessed and the Dispossessed: Spirits, Identity and Power in a Madagascar Migrant Town. Berkeley, California: University of California Press, 1993; 174-176.

7. Ibid., 471.

8. Ibid., 475.

9. See Patrice Callet, Tantaran'Andriana eto Madagasikara; Documents Historiques d'après les Manuts Malgaches, Tom. II. Antananarivo: Tranoprintim-pirenena, 1908. The Tantara, the name by which these documents are known, were written and compiled at least fifty years after the events recorded in them occurred. See also William Ellis, History of Madagascar, Comprising also The Progress of the Christian Mission Established in 1818; and an Authentic Account of the Persecution and Recent Martyrdom of Native Christians. London: Fisher, Son and Co., 1838. Ellis based much of his account on missionary diaries of the time. 
kingdom. ${ }^{, 10}$ Immediately after the execution, Radama visited the missionaries to assure them of his continued favor. David Griffiths, one of the London Missionary Society missionaries present, recorded that the king dismissed the reaction of the protestors, saying that the women "wished to remain forever in ignorance, be like beasts, and fools", as they were unwilling to be "instructed, and become wise, and like Europeans"; according to Griffiths, the missionaries thanked the king for his regard and protection. ${ }^{11}$

There are many questions we could ask about this story. What were the events that preceded Radama's decision to cut his hair? How had the king come to the point that he was willing to execute women of his own class, his own nursemaids, in order to protect the Europeans in the country? And why was it the women of the country who took the risk to stand up and protest policy change that all accounts of the period make clear had disquieted the entire population?

In this paper, I seek to answer these questions and pose others about the protest style of Malagasy women. The issue before us is this: in 1822 Malagasy women and men were oppressed. As I will show, Malagasy women and men continue to suffer multifaceted oppression today. It is striking, then, that it is only Malagasy women who protest and openly resist oppression and unfreedom visited upon them from a host of sources. I seek to answer why.

In part two, I will outline the position of women in Malagasy church and society today. In part three, I discuss the unique role of women in Malagasy public speech - one of confrontation and risk-taking. In part four, I discuss how domination and resistance interrelate and how this plays out in Madagascar. Finally, in part five, I discuss the protest of Malagasy Christian women, citing three groups of Malagasy women church leaders who exemplify the theory I am expounding.

\section{Women's Place in Malagasy Church and Society}

Perhaps because the protesting women in 1822 were aristocrats, they felt they had the right to speak to the king from their position of relative safety. Sadly, women in Malagasy society and church today, as in 1822, cannot speak - or live - freely with safety and protection. Madagascar is a remarkably poor country, where unfreedom and oppression run deep. The opportunity all Malagasy people, particularly outside the cities, have for education is small; women have less opportunity than men, and illiteracy among women is markedly higher than it is for men. ${ }^{12}$ This reality has had a deleterious impact on women's participation in political and community processes. Madagascar has the highest rate of maternal malnutrition in sub-Saharan Africa and a resultant high rate of maternal mortality as well. ${ }^{13}$ Violence against women is accepted as a norm by the culture. ${ }^{14}$ While the birthrate nationally hovers around six live births per woman, in rural areas, $10-14$ children per woman is more common $;{ }^{15}$ it is perhaps not surprising, then, that one in 20 pregnant women in Madagascar will die in childbirth from a web of causes ranging from lack of access to health care to inappropriately close spacing of births. Sexual activity starts on average at age 11 for rural girls, and in the countryside, girls are often initiated into sexual life by a male relative. ${ }^{16}$

Additionally, it is clear that in general in Madagascar, women work harder and longer than

10. Ellis, 288-289.

11. Journal of David Griffiths, entry of 16 April 1822. LMS archives, quoted in Larson, 475.

12. UNICEF, The State of the World's Children 1999. New York: United Nations Children's Fund, 107.

13. USAID, Nutrition of Young Children and their Mothers in Madagascar 1997, Demographic and Health Surveys. Calverton, Maryland: Macro International, 1998; 42.

14. Sharp, 216-221.

15. Comité Technique de Réforme du Service Public, L'Ajustement Structurel à Madagascar Année 1999. Antananarivo: Secrétariat Technique de L'Ajustement, 2000; 152.

16. Sharp, 237-240. 
men. One of my students, a woman theologian in the Malagasy Lutheran church, documented in her master's thesis the daily life of women in her region, along the southeast coast. The tasks that women perform are many and varied. These tasks include care of the home; care of the children; care of extended family, including any who are sick, disabled, dying, and all tasks required when someone dies; responsibility for gathering food and preparing meals; various tasks around cultivating and harvesting crops, especially rice; managing the family's money; education of children, including all schoolwork, cultural education, religious education, and education on chores; and working to make income to supplement the husband's salary. The student stated that in the area where she grew up, one never saw any but the youngest little girls (under four years) playing, while it was common to see groups of boys at play. ${ }^{17}$ This differing socialization based on sex has a significant impact on self-understanding for both boys and girls.

In the two Protestant Malagasy churches with whom I serve, one Reformed and the other Lutheran, women suffer significant oppression as well. Some of this has roots in both early and contemporary missionary practice. Line Nyhagen Predelli has documented the efforts of missionary women to "elevate heathen women" in Madagascar, which actually resulted in the Malagasy women's increased unfreedoms. ${ }^{18}$ Because of the egalitarian tradition of male-female relations in the highlands, women and men were each assigned particular (and by the understanding of the culture, equal) tasks in rice cultivation. As sociologist Øyvind Dahl states about the cultures of highlands Madagascar, "The genders are perceived as complementary in the agricultural production of the domestic unit." 19 However, European mission women came from a context with very different gender relations. Norwegian mission women encouraged the Malagasy women's eschewing "hard, manly labor", such as involvement in agriculture and provision and transportation of water and firewood, all of which was traditional women's work in highlands Madagascar cultures. ${ }^{20}$ Unwittingly, the missionary women decreased Malagasy women's freedom, power and authority by imposing their own sense of what "Christian female behavior" would look like. The choice to stop Malagasy Christian women from taking part in their traditional work in public proved the foundation for the increase of unfreedoms for Malagasy Christian women, because women's participation in agricultural work formed - and forms - the foundation of their status in the family and community. Predelli states,

Missionary women believed the Christian ideal of domesticity was responsible for their own elevation and liberation, and they actively sought to impart that same ideal to presumed heathen women abroad. ${ }^{21}$

In so doing, they actually produced more harm than good. Predelli's research concerned the work of $19^{\text {th }}$ century mission approaches; later research and analysis of $20^{\text {th }}$ century missionsponsored agricultural enhancement projects in Madagascar shows that mission approaches often continue to assume a European model of women's freedom that is not contextually appropriate in Madagascar. ${ }^{22}$

17. Marie Angèle, “Fampandrasoan 'ny Vehivavy amin'ny Faritanan'ny Farafangana”, Thèse Maîtrise, Fianarantsoa; Madagascar: Sekoly Ambony Loterana momba ny Teolojia, 2000, 11.

18. Line Nyhagen Predelli, Contested Patriarchy and Missionary Feminism: The Norwegian Missionary Society in Nineteenth Century Norway and Madagascar. Doctoral Dissertation, University of Southern California. 1998.

19. Øyvind Dahl, Meanings in Madagascar: Cases of Intercultural Communication. Westport, Connecticut: Bergin and Garvey, 1999, 97.

20. Predelli, 85 .

21. Ibid., 97.

22. Marianne Skjortnes, "Gender and Social Change in Merina Rural Society", in Rakotoarisoa Jean-Aimé, ed. Taloha 13: Rethinking "la femme malgache”: New Views on Gender in Madagascar. Antananarivo: Institut de Civilisations - Musée d'Art et d'Archéologie, Université d'Antananarivo, 2000; 222. 
Missionaries today in Madagascar can produce women's unfreedom by sometimes following official mission agency policies that understand conversation about women's ordination by missionaries to be "interference". In some mission-funding and mission personnelsending agencies, including some operating in Madagascar, female missionary personnel who are clergy can be called to serve with churches that do not ordain women - they simply cannot act as pastors in their work, because, as one representative told the faculty on which I serve, "that would be interfering in the internal politics of the host church." 23 Apart from any theological, incarnational or ontological discussion of exactly how one set aside for ordained service in the church stops "acting as a pastor", there is some shaky logic at work here. Politically correct verbiage about the purpose of the mission endeavor aside, the truth is that transformation - change - which is sometimes understood as interference is at the heart of mission work. Missionaries interfere by their very presence in the country and church of service, and certainly by their work. Missionaries come to the field to change things - that is why they are there. It seems clear that the decision not to "interfere" on the issue of women's ordination is made because of the lack of priority put on the ordination of women - and on the freedom of women - and not because of any primacy of "not interfering" in overall mission policy. The issue of ordination is primary for the freedom of women, and the lack of the option to follow God's call into ordained service is a sign of significant unfreedom for women and for the whole church. Experiencing the visible, tangible model of freedom for ordination for all people so called by God is a powerful sign of a church's acceptance of the freedom of God. When this sign is not available, freedom decreases and the openness of a church to the freeing wind of the Spirit is closed off.

However, having a church body open themselves to ordaining women does not mean that full freedom to follow God's call has come. I serve two churches in Madagascar, the Malagasy Lutheran Church and the Church of Jesus Christ in Madagascar. The Lutheran church does not ordain women and the Church of Jesus Christ does; but there are strict limits within the Church of Jesus Christ on what women pastors are 'allowed' to do and on the kinds of places they are permitted to serve. Women clergy are seen as something of a problem to some FJKM leaders, particularly if they are not married to pastors, as placement of single women clergy is understood as difficult. In both the Lutheran and Reformed churches, theologically trained women experience great difficulty when seeking appointment for church work. There is a commonly-held sense that women are not strong enough to do the work, ${ }^{24}$ which would seem to contradict the stark reality that it is the women in Madagascar are doing most of the work there is to do. In addition, in the instances where women are able to somehow find appointment to church service, they have clearly been able to effect a "ministry of presence" to address a number of issues that oppress women arising from Malagasy culture, which to the present day have not been addressed by the Protestant churches. But their absence from positions of church leadership leaves the addressing of these unfreedoms to men; and unfortunately, many of the unfreedoms suffered by Malagasy women receive sanction and approval from male church leaders today in Madagascar. Let me share a few examples.

1) While both churches with whom I serve offer family planning services through their health care systems, most pastors preach against the use of family planning and equate contraception with murder; and attempts to make abortion legal in Madagascar have been condemned by the churches. ${ }^{25}$ The impact of this is to demonize women who for reasons of

23. Minutes of Faculty meeting, Lutheran Graduate Seminary, February 2001.

24. Personal communication, Pastor Andriamasinoro Fidimalala, Tale, Amboniavaratra Theological College FJKM, and Dr. Randrianasolo Joseph, Doyen, Lutheran Graduate Seminary, FLM.

25. Phillip M Allen, Madagascar: Conflicts of Authority in the Great Island. Boulder, CO: Westview Press, 1995 ; 
health, sanity and the welfare of the entire community choose to limit, by any method, the number of children they will bear or to appropriately space births for optimum health for both mother and child; most Christian women do not choose to withstand the church's disapproval.

2) Wife-beating is seen as an acceptable and normal part of married life. A typical pastoral response to wife abuse was found in a research project entitled "Forming the Perfect Marriage", a pastoral student encouraged wives who were beaten to forgive their husbands. When questioned in oral defense, the student said that if a wife complained to him of abuse, he would visit the couple at home to discern what the wife was doing that was causing her husband to beat her and to encourage her to stop troubling him so the abuse would stop. ${ }^{26}$

3) Although a woman in Madagascar has no cultural right to refuse sex, and no Christian woman is understood to favor the use of contraception, Malagasy Christian women and girls who get pregnant outside marriage are barred from receiving communion from the time the pregnancy becomes apparent until the child is three months old. Then the mother can, if she desires reentry into full participation in the life of the Christian community, stand in front of the congregation during Sunday worship and make a public confession of her $\sin .{ }^{27}$ Over six years, each of the pastors among my students has required a number of women in their pastoral ministry to take part in this public humiliation; but my students have not been able to recall one instance where a man was temporarily barred from Holy Communion or required to publicly confess. This is ethically problematic, to say the least. It is an unpastoral response to personal crisis, and in the most simple terms, it is the punishment of one person for the sin of two people. It is also capricious in its application of ecclesiastical penalty; the one of those two who received the punishment was not, in many cases, an active agent in the sin (but rather the victim of the sin) that resulted in pregnancy. The active agent in the sin does not receive punishment, because in many cases, while the pastors know who the father of the child is, the man is either married and / or is an older relative of the mother of the child. To not cause community embarrassment and because of the communal acceptance of this practice, the (often young) woman is made to sacrifice her public reputation on behalf of the man, who was the agent of the $\sin .^{28}$ (Many Christians will privately admit that this practice is wrong and abusive.) This inequality produces great freedom for men to continue sinning and great unfreedom for women to be agents of their own lives, as well as agents in the lives of their children.

\section{Women's Role in Public Speech}

Logic suggests that people who are oppressed would be slow to risk confronting the oppressor for fear that the oppression would increase. So it is surprising that it is the women in Madagascar, who know best the reality of deep and abiding oppression and unfreedom, who are those who take the cultural role of "she who confronts evil and tells the truth". Sociologist Paul Hanson agrees with Dahl in his evaluation of the role of Malagasy women in kabary, the ritual Malagasy speech form used in ceremonial, community celebration and decision-making occasions. Kabary is carried out under rather strict, formulaic guidelines, including the need not

155.

26. Haja Wilson, "Forming the Perfect Marriage", Thèse Licence. Fianarantsoa: Sekoly Ambony Loterana momba ny Teolojia, 1999, and oral defense of thesis, June, 1999.

27. Fiangonana Loterana Malagasy. Lalam-Panorenana sy Fitsipika. Antananarivo: Trano Printy Fiangonana Loterana Malagasy, 1993; 49, and 40.

28. Class discussions of this practice in both churches over six years provide the background information on how this part of church law is actually applied. 
to offend and the avoidance of direct confrontation - it is a very polite speech form. Skillful mpanao kabary or mpikabary (kabary speakers) will attend carefully to these rules, including the "de-emphasis of self" and an "avoidance of bringing attention to other individuals in the group ... the speaker is ... careful to direct attention away from both himself (therefore avoiding pride ...) and others (thus avoiding the harm to them that might follow from either jealous ancestors and humans). ${ }^{, 29}$

Conversely, women are generally understood as too emotional to do kabary. Women's speech is said to be just resaka, everyday conversation, not fit for kabary. Women are understood as 'long tongues' (lavalela) who are constantly engaged in 'gossip' (fosafosa), and are perceived as persons who intrinsically do not have the proper respect to take part in kabary - we are just too immature to understand how to do it $!^{30}$ So, it is interesting to note that the role many scholars see women often playing in kabary - and communities often calling women to play - is to bring their gift of emotion, of plain speech, and their willingness to confront into community discussions. It is just in those places that men, strictly adhering to kabary rules, are not allowed to confront, not to speak the truth, that women are called to step in and tell the situation like it is. ${ }^{31}$ Hanson calls these female confrontations "frequent normative transgressions". ${ }^{32}$ Within Malagasy women's public speech, Hanson documents evidence of the willingness of women to take risks that men will not take, indicating a complex of forces of domination, subordination and resistance at work in community relations, and a singular willingness on the part of women to challenge the social order so as to renew it. ${ }^{33}$ Hanson describes these skills effecting "the reparation of breakdown in men's oratorical exchanges and the confrontation of anti-social actions. ${ }^{, 34}$

\section{Interaction of Domination and Resistance}

So why would Malagasy women take on the risks of confronting and protesting, knowing as they do that oppression and opprobrium are sure to follow? Why is it Malagasy women, the most unfree group within Malagasy society, who stand up and speak truth to power, while those in more privileged and powerful positions (that is, men) accept the oppression that comes their way?

James C Scott's description of "official" and "hidden" transcripts and the ways these operate in relationships of dominant and subordinate groups may help us here. ${ }^{35}$ The official transcript is the official line, the standard understandings dominant groups hold of their place in the world, the rationale(s) necessary to hold that role in place, and the accepted understandings of the subordinate group. Hidden transcripts are what the subordinates know and feel free to discuss with one another in private - about the dominant groups, about individual members of the dominant group, about power relations. Scott's sense of the hiding of the hidden transcript, and the polishing and maintaining of the official transcript, as primary among the "key survival

29. Paul W Hanson, "Women in Action, Councils in Change: The Productivity of Women's Speech Styles in Madagascar's Ranomafana National Park" in Rakotoarisoa Jean-Aimé, ed. Taloha 13: Rethinking "la femme malgache”: New Views on Gender in Madagascar. Antananarivo: Institut de Civilisations - Musée d'Art et d'Archéologie, Université d'Antananarivo, 2000, 275.

30. Ibid., 263-294; cf. also Dahl, 152-153.

31. Ibid., Hanson and Dahl.

32. Ibid., see also Larson, $475 \mathrm{ff}$.

33. Ibid., 281-282.

34. Ibid., 263.

35. James C Scott, Domination and the Arts of Resistance: Hidden Transcripts. New Haven, CT: Yale University Press, 1990. 
skills of subordinate groups" ${ }^{36}$, and, indeed, a key skill for dominant groups as well, is helpful to our discussion here. To keep the status quo, both groups work hard at holding up the hegemonic voices and practices - the dominant because it keeps their position intact, and the subordinate out of fear. Scott argues that "... a partly sanitized, ambiguous, and coded version of the hidden transcript is always present in the public discourse of subordinate groups. ${ }^{37} \mathrm{Scott}$ promotes the idea of the indivisibility of different kinds of domination, and shares a sense of the similar characteristics various forms of domination take. ${ }^{38}$ But Scott notes that resistance to domination is a regular response, and that the responses and forms of resistance subordinate groups take are similar, no matter the different forms the subordination may take.

We learn from the story of the Merina women confronting the king in 1822 in Madagascar, and from research showing the role women are willing to play, the risks they are willing to take, in frequently and normally breaking the rules of kabary, that in Madagascar, women may be willing to stay quiet for the sake of the greater good for some time - until the violation of freedom, not just for women but for the whole community, reaches the breaking point. It is at that point that the official transcript explodes and confrontation takes place. For Malagasy women in 1822, an entire system of oppression had become evident, all seemingly tied to the missionary presence on the island and Radama's efforts to encourage Malagasy ties with Europe. The women were not acting simply against their own oppression, but against their sense of the new oppression and unfreedom being suffered by the whole community. In contemporary Madagascar, when it becomes clear that to renew and free the community, confrontation and truth-telling will be needed, it is Malagasy women who step forward and take the required risk so that the whole community may benefit. Women will generally "keep their place" and remain at home, "attending to their domestic duties", as the king suggested. The "domestic duties" of women are, as we have seen, quite enough to fill one's time most days! But when the oppression for women, for children, for families, and for the whole community becomes too great, in many cases, Malagasy women stand up and speak out.

In these cases, the fact that it is women who are seen taking the risk to confront the powerful may be because women have more experience with the reality of day-to-day oppression. The stories we have shared are multi-layered with both domination and subordination. The interplay of the British missionaries; the king; the British government and the London Missionary Society; the aristocratic men of the kingdom; the aristocratic women of the kingdom; and the host of other Malagasy societal layers below the aristocrats, including other members of the Merina people group and descending to those held as slaves, show many facets and sides, sometimes contradictory sides, to the story. Throughout the many layers of domination and subordination, women play a unique role of always being in a subordinate role to someone (almost always some man or men), even when their placement in the system is quite high. Perhaps it is because of this almost-universal female experience of subordination and oppression that women have learned the mechanics of confronting authority better than men who are oppressed. In addition, women need not fear losing power and authority, as they don't generally have it in the first place - with little to lose, it may be easier for them to consider confrontation as a viable response to oppression.

\section{The Protest of Christian Women}

Christian women hold a particular place among those who are oppressed and who resist and protest their oppression and unfreedom. Christian women deal with not only the oppression of 
culture and society, but sadly also the oppression of misogynous and inaccurate understandings of the perspective of God and Jesus on women, which in the African church can be pervasive. The truth that Christian women find the strength to resist and to protest their unfreedom has a unique source - the understanding Christian women have of God. Mercy Amba Oduyoye explains the position of African Christian women who are oppressed by not only men but by the "official transcript" heard in the churches about the proper role of women and the proper relationship of women and men under Christ. Despite centuries of oppression and androcentric messages addressed to them in church, Oduyoye says that African women "experience God as empowering them with a spirituality of resistance to dehumanization"; thus, the sexist and oppressive interpretation common in African cultures and the church in Africa "have not been able to warp women's direct experience of God as a loving liberator."39

In discussing liberation for African women, Teresa Hinga asks: "Who is Christ? And what does belief in him mean, particularly for those who find themselves caught up in conditions of oppression?" ${ }^{40}$ After discussing two historical, and contradictory, images used for Christ in the past in Africa (Christ the conqueror, who seemed to legitimize the subjugation of whole races of people; and Christ the liberator, who seemed to be leading the fight for the abolition of slavery) ${ }^{41}$ Hinga offers three alternative images of Christ in Africa that have implications for women. Hinga's views of Jesus as Friend, the Christ of charismatic renewal, and Christ the iconoclastic prophet each lend power to Christian women working to resist societal and ecclesiastical oppression and unfreedom. Hinga states:

... for Christ to become meaningful in the context of women's search for emancipation, he would need to be a concrete and personal figure who engenders hope in the oppressed by taking their (women's) side, to give them confidence and courage to persevere. Secondly, Christ would also need to be on the side of the powerless by giving them power and a voice to speak for themselves. Thirdly, the Christ whom women look for is one who is actively concerned with the lot of victims of social injustice and the dismantling of unjust social structures. $^{42}$

All three of these images have a transformative edge. Jesus as friend to the powerless, Jesus as the power of the Spirit of God, and Jesus as prophet who upsets the present power structures all three are powerful images of a Savior who is not satisfied with the ways things are and who has the power, and will use the power, to change the situation.

Below I discuss three groups of Malagasy Christian women in leadership in the church and some of the ways in which Malagasy Christian women embody these three views of Jesus and take power from these perspectives for the work of resistance. I will speak of the role of Malagasy Christian women in development; the role of women in the indigenous charismatic Christian movement, the Fifohazana; and the role of Malagasy Christian women as church leaders.

a) Malagasy Christian women in Development Ministries

Because of the belief Malagasy Christian women have in Jesus as their friend and as friend to all who are not free, it is women who are at the forefront of church development ministries.

39. Mercy Amba Oduyoye, "The African Experience of God through the Eyes of an Akan Woman", in CrossCurrents, Winter 1997-98. New York: Association for Religion and Intellectual Life, 1998.

40. Teresa M Hinga, "Jesus Christ and the Liberation of Women in Africa", in Mercy Amba Oduyoye and Musimbi RA Kanyoro, eds. The Will to Arise: Women, Tradition, and the Church in Africa. Maryknoll, NY: Orbis Books, 1992; 183.

41. Ibid., 186-190.

42. Ibid., 191-192. 
This is very good, because as many development scholars have shown, the agency of women in the work of development is a crucial, and perhaps the crucial, element required to make a project or initiative work. If women are involved, their empowerment empowers all those around them. If women are not involved, the potential for transformation leading to freedom is severely limited. ${ }^{43}$

These truths are borne out by the experiences of church development workers I have interviewed in Madagascar. Dr. Rahelimahefa Jeanine, national coordinator for the Primary Health Care program of the Malagasy Lutheran Health Service, spoke about an effective approach used by her program to do community health education. When the program does a community assessment, they start with women:

...we gather some women ... and work with them ... We gather groups of women and we teach them first, to give them the approach that they should have ... they sensitize other people, little by little ... women are the power that is development. ${ }^{44}$

It is through women's agency, states Dr. Rahelimahefa, that positive change occurs. Sosana, a nutritionist with the Integrated Evangelism and Health Team Ministry, agrees; she states that the major positive changes she has seen in the area in which she works have been brought about by the participation of women, taking the roles of association member; community education worker; or participant in community projects, such as vaccination or experiments in farming. It is the women, Sosana says, who are willing to try new things, and women are the people who have the most direct impact on the children and the family. ${ }^{45}$

Additionally, a look at student research may be helpful. As part of my teaching in Madagascar, I advise students on the writing of theses. Over the past five years, 86 men and 17 women have graduated from the seminary. Of that number, 14 of the women have written their masters' theses on some aspect of development. Of the 86 men, a single student has chosen to write on a development issue. These numbers indicate something. Perhaps the women are seeing something the men are not; or perhaps the women feel the freedom, from their humble position with very little power or voice, to engage in research not seen as properly "theological" or "spiritual" by church leaders. Perhaps the socialization women receive that engenders a sense of responsibility for the human and natural communities encourages them to discern subjects for reflection which the men do not see; or perhaps the ways in which women are given permission to openly confront hard truths, a permission not received by Malagasy men, leads the women to delve into difficult issues. I believe that women's understanding of Jesus as a friend to the powerless, and as their own friend, is part of why women see what men in the church do not see.

\section{b. Malagasy Christian Women in the Fifohazana}

In Hinga's discussion of her second image of Christ, the Christ of charismatic renewal, ${ }^{46}$ she

43. See Amartya Sen, Development as Freedom. New York: Anchor Books, 1999; particularly chapter eight, "Women's Agency and Social Change", 189-203.

44. Interview with Dr. Rahelimahefa Jeanine, national coordinator, Primary Health Care, SALFA-FLM, April 29, 2002. The two interviews cited here are included in the author's forthcoming dissertation, Freedom as Development: A Proposal for the Protestant Churches of Madagascar. Doctoral dissertation, School of Theology, University of Natal, Pietermaritzburg, South Africa, 2003.

45. Interview with Ms. Sosana, nutritionist, SALFA Team Ministry Primary Health Care Program, Ejeda, May 8, 2002.

46. Hinga, 191. 
explores the role of Christ in the development of indigenous movements and churches that emphasize the work of the Spirit; in them, Jesus becomes the embodiment of the work of "the Spirit, the power of God, and the dispenser of the same to those who follow him." Hinga notes that movements that emphasize the work of the Spirit in this way are particularly popular with women; she notes that women are typically given greater voice in such movements, which explains their attraction for women. Hinga could be describing the Fifohazana movement of Madagascar, an indigenous, mostly lay-led Christian renewal founded at a time when both mission and colonial power was growing on the island. The role of the Fifohazana movement in the life of church and society in Madagascar can scarcely be overstated. Women make up more than $80 \%$ of the mpiandry, the lay shepherds involved in the casting out of demons, care for the ill (particularly the mentally ill), prayer, worship and Bible study. Women are encouraged as leaders in the Fifohazana, a chief difference between this parachurch movement and the churches themselves.

The status of women in the Fifohazana movement is at least in part due to the status of women in exorcism in traditional Malagasy practice. As Lesley Sharp notes, the mpiandry are not alone in offering exorcism services to the Malagasy. ${ }^{47}$ Spirit possession is a common malady in Madagascar and exorcism is practiced by a wide variety of traditional healers. Spirits are understood as victimizing more women than men, and women are seen in many Malagasy cultures as particularly effective in the arts of demon/spirit exorcism. ${ }^{48} \mathrm{In}$ this cultural context, then, it is natural that Christian women would be attracted to the Fifohazana movement, which integrates some Malagasy cultural understandings with Christian spirituality and practice. While the movement was started by a man in the 1880 's, the most famous mpiandry was a woman. ${ }^{49}$ Women do have freedom to participate in this movement at all levels, in part because of the cultural understanding of their place vis-a-vis the spirit world - and in part because the movement understands that the Christ of charismatic renewal calls upon both men and women to be leaders and to speak with his voice to the community.

\section{c. Malagasy Christian women as church leaders}

Hinga raises a "third face of Christ", that of Christ as iconoclastic prophet. This Jesus "stands out in scripture as a critic of the status quo", particularly when it creates and sustains injustice. ${ }^{50}$ Women church leaders in Madagascar identify particularly with this image of Christ. While the two churches with whom I serve do not share a common policy on the ordination of women, in neither church is justice in the treatment of theologically trained women incarnated in the stance of the church, officially or informally. In both churches, examples exist of women receiving high marks on seminary admittance exams, yet not being admitted to theological education. In most school terms during my years in Madagascar, women students have held the highest academic standing at both schools. Yet many male students at both schools feel a strong sense of permission to make fun of their female colleagues. Malagasy women pastors and church leaders report that sexual harassment from male church professionals is a common part of their life. In that men are rarely prosecuted in Malagasy society for crimes against women, and the churches follow the culture on this point, this suggests an ecclesiastical viewpoint that favors cultural views more than it does the health and welfare of women. This suspicion is borne out by the experience of theologically trained

47. Sharp, 174-176, 267-269.

48. Ibid.

49. Volahavana Germaine, known as Nenilava ('Tall Mother'), the great and influential prophetess of the movement and undisputed leader for over 50 years until her death in 1997.

50. Hinga, 191. 
women seeking church employment. Both churches are growing exponentially and urgently seeking more candidates for ministry because each new pastor must serve at least five, and often 10-20, churches and preaching stations, often walking a number of kilometers between sites. Yet both churches see women as hard to place.

Malagasy women church leaders and pastors know the injustice of their situation and understand the injustice borne by all women in Malagasy society. Their understanding of Christ as the one who will stand by them in the struggle, who empowers their resistance, who makes them strong when the burdens seem too hard to bear, is what gives life to their ministry.

Malagasy women church leaders and pastors rely on Christ the iconoclastic prophet, who took great risks himself in order to follow God's call, in their journeys of faith.

\section{Where am $I$ in all of this?}

Finally, I present this research as a friend to Malagasy women. As the only ordained woman working with the Malagasy Lutheran Church given the freedom by my sending churches, the Evangelical Lutheran Church in America and the Presbyterian Church (USA), to "act as a pastor", and as the only clergywoman missionary working with the Church of Jesus Christ in Madagascar, I stand as a symbol to nearly everyone I meet and with whom I work. For some, I am a symbol of freedom, justice, and opportunity to serve as God calls. For others, I am a symbol of the churches of the West imposing their values, their culture, and their view of women on the Malagasy church. I have come to learn in six years in Madagascar that no one in the church has a neutral stance about my presence and ministry there.

I have also come to learn that I am a spiritually weaker person than the women church leaders and pastors of Madagascar. The churches that sent me, both the Evangelical Lutheran Church in America and the Presbyterian Church (USA), flawed as they are, do not present the open challenges to women who feel a call to ordained service that the churches in Madagascar do. Thus, in my ministry before I came to the island, I did not have to expend excessive energy in the ministry of resistance to the kind of overt, unapologetic and interminable sexism and violence against women that is a daily reality in Madagascar. There's nothing like deep and abiding oppression to sharpen one's resistance skills!

I have learned from Malagasy Christian women that one can persist in the struggle, no matter how tired, no matter how worn, no matter even how truly hurt and attacked one is, if one is sustained by the power of Jesus. Malagasy women are called, by their society and culture, by their own giftedness, and by the Holy Spirit of God, to persist in their protest, knowing that Jesus believes in freedom and so they must also believe. Those who protest do so because they believe that their protest will ultimately prevail and end in increased freedom. I honor the protest and bravery of Malagasy Christian women, past and present, and pray that the day will come when their struggle will end and they will know freedom. 


\section{BIBLIOGRAPHY}

Allen, Phillip M 1995. Madagascar: Conflicts of Authority in the Great Island. Boulder, CO: Westview Press.

Callet, Patrice 1908. Tantaran'Andriana eto Madagasikara; Documents Historiques d'après les Manuts Malgaches, Tom. II. Antananarivo: Tranoprintim-pirenena.

Comité Technique de Réforme du Service Public, L'Ajustement Structurel à Madagascar Année 1999. Antananarivo: Secrétariat Technique de L'Ajustement, 2000.

Dahl, Øyvind 1999. Meanings in Madagascar: Cases of Intercultural Communication. Westport, Connecticut: Bergin and Garvey.

Ellis, William 1838. History of Madagascar, Comprising also The Progress of the Christian Mission Established in 1818; and an Authentic Account of the Persecution and Recent Martyrdom of Native Christians. London: Fisher, Son and Co.

Fiangonana Loterana Malagasy 1993. Lalam-Panorenana sy Fitsipika. Antananarivo: Trano Printy Fiangonana Loterana Malagasy.

Haja Wilson 1999. "Forming the Perfect Marriage", Thèse Licence. Fianarantsoa: Sekoly Ambony Loterana momba ny Teolojia.

Hanson, Paul W 2000. "Women in Action, Councils in Change: The Productivity of Women's Speech Styles in Madagascar's Ranomafana National Park" in Rakotoarisoa Jean-Aimé, ed. Taloha 13: Rethinking "la femme malgache": New Views on Gender in Madagascar. Antananarivo: Institut de Civilisations - Musée d'Art et d'Archéologie, Université d'Antananarivo.

Hinga, Teresa M 1992. "Jesus Christ and the Liberation of Women in Africa", in Mercy Amba Oduyoye and Musimbi RA Kanyoro, eds. The Will to Arise: Women, Tradition, and the Church in Africa. Maryknoll, NY: Orbis Books.

Holder Rich, Cynthia 2003. Freedom as Development: A Proposal for the Protestant Churches of Madagascar. Doctoral dissertation, School of Theology, University of Natal, Pietermaritzburg, South Africa, Appendix II, Interviews.

Larson, Pier Martin 1992. Making Ethnic Tradition in a Pre-Colonial Society: Culture, Gender and Protests in the Early Merina Kingdom, 1750-1822. Doctoral Dissertation, University of Wisconsin-Madison, USA.

Marie Angèle 2000. "Fampandrasoan'ny Vehivavy amin'ny Faritanan'ny Farafangana", Thèse Maîtrise, Fianarantsoa; Madagascar: Sekoly Ambony Loterana momba ny Teolojia.

Oduyoye, Mercy Amba 1998. "The African Experience of God through the Eyes of an Akan Woman", in CrossCurrents, Winter 1997-98. New York: Association for Religion and Intellectual Life.

Predelli, Line Nyhagen 1998. Contested Patriarchy and Missionary Feminism: The Norwegian Missionary Society in Nineteenth Century Norway and Madagascar. Doctoral Dissertation, University of Southern California.

Ratovoson, Celine 1989. "La Femme Malgache Responsable de son Environnement Physique et Systemes Religieux", in CIDST, La Femme Malgache Responsable de sonEnvironnement. Antananarivo: L'Académie Malgache.

Scott, James C 1990. Domination and the Arts of Resistance: Hidden Transcripts. New Haven, CT: Yale University Press.

Sen, Amartya 1999. Development as Freedom. New York: Anchor Books.

Sharp, Lesley A 1993. The Possessed and the Dispossessed: Spirits, Identity and Power in 
a Madagascar Migrant Town. Berkeley, California: University of California Press.

Skjortnes, Marianne 2000. "Gender and Social Change in Merina Rural Society", in Rakotoarisoa Jean-Aimé, ed. Taloha 13: Rethinking "la femme malgache": New Views on Gender in Madagascar. Antananarivo: Institut de Civilisations - Musée d'Art et d'Archéologie, Université d'Antananarivo.

UNICEF, 1999. The State of the World's Children 1999. New York: United Nations Children's Fund.

USAID, 1998. Nutrition of Young Children and their Mothers in Madagascar 1997, Demographic and Health Surveys. Calverton, Maryland: Macro International. 